openUP

\title{
A neoclassical investment function of the South African economy
}

\author{
Charlotte du Toit, Elna Moolman
}

\begin{abstract}
In this paper, investment is estimated to be consistent with a neoclassical supply-side model of the South African economy. In the neoclassical tradition, the model has to allow for profit-maximising or cost-minimising decision-making processes by firms, where supplyside factors such as taxes, interest rates and funding in the broader sense, play a significant role. Internal and external financial constraints have an enormous influence on South Africa's gross domestic fixed investment, as was demonstrated clearly by the vulnerability during, for example, the imposition of international sanctions against South Africa as well as during the East Asian and Russian crises. Therefore, in modelling gross domestic fixed investment for South Africa, it is necessary to incorporate the significant role played by financial constraints (internal and external) on investment.
\end{abstract}

Keywords: Investment; User cost of capital; South Africa

\section{Introduction}

In this paper, a model of aggregate fixed investment is proposed, derived and estimated. There are a number of reasons why investment plays an important role in determining gross domestic product (GDP) in an economy. First, investment increases a country's productive capacity, providing that investment outlays are on durable goods with a relatively long life-span and also that they embody the most recent technical advances. Second, investment expenditure induces shifts in the 


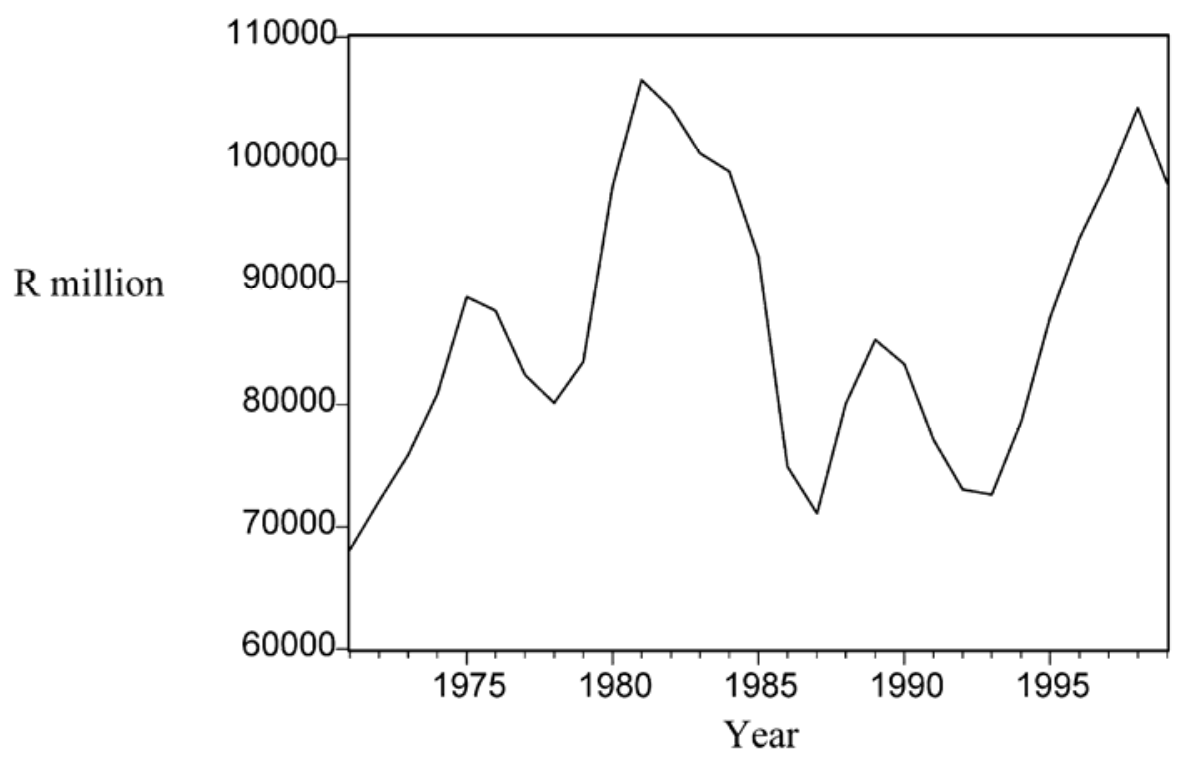

Fig. 1. Gross domestic fixed investment in South Africa, 1970-2000.

aggregate levels of employment and personal income by affecting the demand for capital goods. In the third place, empirically, investment is a highly volatile component of GDP. Given this volatility and the fact that investment movements have important consequences for productive capacity, the demand for labour, personal income and the balance of payments, it is important to understand the fundamental causes of variations in aggregate investment.

Gross domestic fixed investment in South Africa deteriorated significantly with the imposition of economic sanctions and the resulting disinvestment and outflow of foreign capital since 1985. The situation improved with the abolition of sanctions and when disinvestment in South Africa ended in 1994. However, the greater degree of openness of the economy increased South Africa's vulnerability to international financial market instability, as was experienced with the East Asian and Russian crises of 1998. Therefore, in modelling gross domestic fixed investment for South Africa, it is necessary to incorporate the significant role of financial constraints (internal and external) on investment (Fig. 1).

Investment is estimated to be consistent with a neoclassical supply-side model for the South African economy. In the neoclassical tradition, the model has to allow for profitmaximising or cost-minimising decision-making processes by firms, where supply-side factors such as taxes, interest rates and funding in the broader sense play a significant role. This paper is organized as follows. Investment in South Africa is described in the next section. Different theoretical frameworks for investment are presented in the third section. In section four, an empirical function is estimated for fixed investment in South Africa. The conclusion is presented in Section 5. 
openUP

\section{Investment in South Africa}

During the 1970s gross domestic fixed investment in South Africa was characterized by an upward trend with an average growth rate of $3.5 \%$ per annum. However, the situation deteriorated significantly with the imposition of economic sanctions and the resulting disinvestment and outflow of foreign capital after the early 1980s. During the 1980s, domestic fixed investment slowed down to an average growth rate of less than $1 \%$ per annum. The situation improved again with the abolition of sanctions and when disinvestment in South Africa ended in 1994. The average growth rate of gross domestic fixed investment since 1994 was 5.3\% per annum.

The changeover of the South African political system to a democratic dispensation with the country's first non-racial election on 27th April 1994 removed the political barriers that had prevented successful economic adjustment during the 1980s. The abolition of sanctions and disinvestment actions against South Africa opened markets to foreign goods, services and financial flows. During 1995 alone, more than R21 billion worth of foreign capital flowed into the economy (South African Reserve Bank). The initial political stability, a decreasing rate of inflation, record harvests, high real interest rates and a stable exchange rate all served to attract foreign capital, although mainly of a volatile, indirect and speculative nature.

However, the greater degree of openness of the economy increased South Africa's vulnerability to international financial market instability, as was experienced with the East Asian and Russian crises of 1998. In 2001, emerging market concerns and uncertainties about recession in the US, Europe and Japan led to sharp reversals in capital flows and considerable currency volatility in many emerging markets. However, not all of the country's macroeconomic stability problems can be blamed on external factors. South Africa continues to suffer from a number of problems that are potentially serious long-term impediments to sustainable growth and development:

- The domestic savings ratio is inadequate to stimulate investment.

- Economic growth is inadequate to attract domestic and foreign investment.

- Incentives to invest in South Africa are not attractive because the investment process is riddled with red tape and start-up costs are high. Furthermore, high corporate taxes and various other hidden taxes are disincentives for investment.

- The South African labour market remains severely over-regulated and is therefore a disincentive to foreign direct investment (FDI).

- Skills shortages and a lack of policy implementation to address these problems are also a factor.

- Crime levels and the apparent inability of the government to resolve basic issues such as personal safety, have limited FDI. 
- In general, the macroeconomic environment is undermined by a liberalisation process that is constrained by attempts to rectify social imbalances created by apartheid and a privatisation process in which policy implementation often appears to sabotage policy directives.

Uncertainty over the impact of the above-mentioned factors on the economy raises concerns with regard to the country's ability to perform in terms of growth, employment and development. It has become increasingly important to establish the impact of these factors in order to shed light on the government's role in determining priorities for macroeconomic policy.

\section{Theoretical framework}

\subsection{Definitions and general framework}

Aggregate capital stock $(K)$ at the end of time period $t$, assuming a constant exponential depreciation $(\delta)$, is referred to as the net capital stock and is defined by:

$K_{t}=(1-\delta) K_{t-1}+I_{t}$.

From Eq. (1) it follows that replacement investment equals $\delta K_{t-1}$ and net investment, defined as the net increment in the capital stock since the previous time period, $K_{t}-K_{t \_u}$ equals total investment minus replacement investment, i.e. $I_{t}-$

$\delta K_{t-1}$.

\subsection{Modelling investment: a survey}

\subsubsection{The accelerator model (Keynesian approach)}

The distinguishing feature of the accelerator model is that it is based on the assumption of a fixed capital/output ratio. This implies that, prices, wages, taxes and interest rates have no direct impact on capital spending but that they may have indirect impacts. The naive accelerator model defines optimal capital stock $K_{t}^{*}$ as a fixed proportion to output $\left(Y_{t}\right)$ :

$K_{t}^{*}=\mu Y_{t}$

with $\mid \mathrm{x}$ denoting the fixed capital/output ratio. Furthermore, since the capital stock is always optimally adjusted in each period, implying $K_{t}^{*}=K_{t}$, net investment $I_{\mathrm{nt}}$ equals:

$I_{\mathrm{nt}}=K_{t}-K_{t-1}=\mu\left(Y_{t}-Y_{t-1}\right)$.

In a generalized version of this model, called the flexible accelerator model, the adjustment of capital stock to its optimal level is no longer instantaneous, but 
instead is assumed to be a constant proportion $\lambda$ of the gap between $K^{*}$ and $K$. Then net investment is:

$I_{\mathrm{nt}}=\lambda\left(K_{t}^{*}-K_{t-1}\right)$.

\subsubsection{The cash-flow model}

The emphasis on capital market imperfections and the significance of financial constraints on investment behaviour are not novel to empirical studies of investment decisions. Three main sources of funds have been identified in various applied research studies of investment. These are internal cash-flow, availability of external debt and equity financing (sales). The cash-flow model posits investment spending as a variable proportion of internal cash-flow ${ }^{1}$ Since the supply of internal funds is obviously affected by the current level of profits, it has been suggested that the optimal capital stock $K^{*}$ should be made dependent not on the level of output but instead on variables which capture the level of profits or expected profits. Grunfeld (1960) assumed that the optimal capital stock is a linear function of expected profits (proxied by the market value of the firm $V_{t}$ ), which yields:

$K_{t}^{*}=\alpha+\beta V_{t}$.

\subsubsection{The neoclassical model: Jorgenson's approach}

The distinguishing feature of the neoclassical model is that it is based on an explicit model of optimisation behaviour, which relates the desired capital stock to interest rates, output, capital prices and tax policies. Consider a firm that produces one output, $Y$, by using two inputs, $K$ and L. Jorgenson (1963) postulated the maximisation of the net worth of the firm as its ultimate objective. The net worth is the amount that a purchaser would be willing to pay for the firm, which again equals the sum of the net present value of the future stream of profits from time zero, subject to a neoclassical production function constraint: $Y_{t}=f\left(K_{t}, L_{t}\right)$.

The optimisation problem is then:

$\max _{K, L, I} V=\int_{0}^{\infty} \exp \left(-R_{t}\right)\left[p_{t} f\left(K_{t}, L_{t}\right)-w_{t} L_{t}-q_{t} I_{t}\right] \mathrm{d} t \quad\left(\right.$ with $\left.R_{t}=\int_{0}^{t} i_{s} \mathrm{~d} s\right)$

Where $i_{s}$ is the rate of interest at time $s$ and $I_{t}$ is gross investment or net purchase of capital stock at time $t$. The output is sold at $p_{t}$ and the inputs for period $t$ are bought at the prices $w_{t}$ and $q_{t}$ respectively. Jorgenson assumes a perfectly competitive

market, which implies that the firm is a price-taker and the firm therefore has to choose $L_{t}, K_{t}$ and $I_{t}$ to maximise the net present value of the firm.

\footnotetext{
${ }^{1}$ A common variable used to measure available funds is cash flow, defined as profits after axes plus depreciation allowances less dividend payments to shareholders. Cash flow has historically accounted for a substantial portion of firms' sources of funding for fixed investment. Cash flow is not, however, the sole source of available funds. Additional sources of funds for investors include debt financing and issuing of shares.
} 
Under the assumption of certainty with regard to all the exogenous variables (output and input prices), it can be shown that this model reduces to its static equivalent and thus encounters the one-period-optimisation problem (Nickell, 1978). The optimisation problem can then be defined as:

$\max _{K, L} \pi_{t}=\pi_{t}\left(Y_{t}, K_{t}, L_{t} ; p_{t}, r_{t}, w_{t}\right)=p_{t} Y_{t}-\left[w_{t} L_{t}+r_{t} K_{t}\right]$

$=p_{t} f\left(K_{t}, L_{t}\right)-\left[w_{t} L_{t}+r_{t} K_{t}\right]$

where $\left\{Y_{t}, K_{t}, L_{t} ; p_{t}, r_{t}, w_{t}\right\} \in R_{+}, \pi \in R, \pi()$ check this variable is at least twice differentiable and $r_{t}$ is the user-cost-of-capital in period $t$.

The Lagrange multiplier procedure yields the necessary conditions for optimality, namely, for capital (Eq. (8)) and labour (Eq. (9)):

$p_{t} \frac{\partial Y_{t}}{\partial K_{t}}=r_{t} \rightarrow \frac{\partial Y_{t}}{\partial K_{t}} \equiv \mathrm{MPP}_{K, t}=\frac{r_{t}}{p_{t}}$

$p_{t} \frac{\partial Y_{t}}{\partial L_{t}}=w_{t} \rightarrow \frac{\partial Y_{t}}{\partial L_{t}} \equiv \operatorname{MPP}_{L, t}=\frac{w_{t}}{p_{t}}$

where $\mathrm{MPP}_{K, t}$ and $\mathrm{MPP}_{L, t}$ denote the marginal physical products of $K$ and $\mathrm{L}$, respectively ${ }^{2}$

In order to estimate Eq. (8) it is necessary to assume an explicit form of the production function. The marginal physical product is then obtained by taking the partial derivative with respect to capital and solving the expression for the level of $K^{*}$ such that the marginal physical product of capital equals the real user-cost-of-capital.

\subsubsection{Tobin's q-model}

Tobin (1969) generalised the cash-flow model and has provided a rigorous framework for an investment model in which net investment depends on the ratio of the market value of business capital assets to their replacement value, a ratio known as $q$. The theory underlying Tobin's $q$ is closely related to the neoclassical investment model considered in the previous section.

Managers determine the price they are willing to pay for an investment project (the demand price for an asset) on the basis of the expected profitability. The demand price for an entire firm is the market value of all its securities. The cost of producing all new capital goods is the supply price and is typically measured by assessing the replacement cost of a firm's assets. In equilibrium, the demand and

\footnotetext{
${ }^{2}$ These equations confirm the theoretical conditions for profit-maximisation, namely, that firms will choose a set of inputs such that for each input, the marginal benefit of employing another unit of the input (additional real output) equals the marginal cost of employing another unit of the input (the additional real wage or real user-cost-of-capital).
} 
supply prices for fixed investment must be equal. If the ratio of the market value of the firm to the replacement value of its assets were unity, then there would be no incentive for the firm to invest.

The naive form of the Tobin's g-model of investment, implying that whenever marginal $q$ is greater (less) than unity, there are incentives for net investment (disinvestment) in capital goods, is specified by:

$$
I_{t}=a+\sum_{i=0}^{m-1} b_{i}(q-1)_{t-i} K_{t-i-1}+b_{K} K_{t-1}+u_{t}
$$

Where $b_{i}$ is expected to be positive.

In practice, there are serious problems in empirically implementing the g-model. Measurement problems, such as measuring the replacement value of the firm's assets (the denominator of $q$ ), valuation of the outstanding debt obligations (the nominator of $q$ ) and determining a marginal rather than an average value for $q$, have contributed to the poor performance of q-models (Berndt, 1991). Furthermore, the underlying theory is vague on the functional form. Although the q-model is relatively attractive because of its theoretical foundations and its ability to distinguish order, delivery and gestation from expectational lags, its empirical performance to date has been less than impressive (Berndt, 1991).

\section{An empirical investment function for the South African economy}

In this section an aggregate gross domestic fixed investment function is estimated based on Jorgenson's neoclassical model. Johansen's cointegration estimation procedure is employed. The resulting investment function is subjected to comprehensive evaluation and testing.

\subsection{The theoretical model}

The neoclassical (Jorgenson) approach is most suitable for estimating a domestic fixed investment function, as it has to be consistent with a supply-side model for the South African economy, which incorporates all cost-minimising and profit-maximising decisionmaking processes by firms. In applying the Jorgenson neoclassical model for the South African case, it is possible to specify the underlying technology to be of Cobb-Douglas nature. ${ }^{3}$

According to neoclassical theory, capital will be employed until the marginal cost of capital equals the marginal product of capital. This can be portrayed as follows:

$$
\mathrm{UCC}=\alpha Y / K
$$

\footnotetext{
${ }^{3}$ Since the investment model in this paper is part of the University of Pretoria's macroeconomic model, this ensures consistency of the supply system as it was proven that a Cobb-Douglas production specification, taking endogenous technical progress into account, is valid and representative of the South African economy (Du Toit 1999, pp. 39-62).
} 
Table 1

List of variables

\begin{tabular}{ll}
\hline Variable & Series \\
\hline$Y$ & GDP at factor cost \\
$K$ & Capital stock \\
UCC & User cost of capital \\
FIN & Financial constraints \\
RL & Nominal long-term interest rate \\
INTPOS & International position \\
SANCDUM & Dummy variable capturing years of \\
& international sanctions against \\
& South Africa (1985-1992) \\
\hline
\end{tabular}

where a should be equal to the elasticity of capital in the production function. The longrun equilibrium level of capital can be obtained from Eq. (11) by normalising on capital. An error correction model can be estimated, as it usually would, to explain short-run deviations from this long-run equilibrium path. For the purposes of accommodating the principles of the cash-flow model, an aggregate financial constraint variable will be included, incorporating both internal (domestic) and external (foreign) sources of funding. The model will also be extended by incorporating a set of international factors (international positional index) to capture the short-run consequences of the high degree of openness of the South African economy.

\subsection{The data}

Table 1 provides a list of all the variables used in the empirical analysis. All these variables, with the exception of the financial constraint and user cost of capital, were obtained from the South African Reserve Bank's Quarterly Bulletin. Sections 4.2.1, 4.2.2 and 4.2.3 explain how the financial constraint, user cost of capital and international position variables are constructed.

\subsubsection{Financial constraint}

For the purpose of accommodating the principles of the cash-flow model, an aggregate financial constraint variable is constructed, incorporating both internal (domestic) and external (foreign) sources of funding. In accordance with the exposition of the national accounts, domestic financial constraints consist of savings by households ( $s p$ ), corporate enterprises (sc), the government ( $\mathrm{sg}$ ), as well as replacement investment or depreciation in real capital stock (depr). External financial constraints consist of net foreign capital flow (cap/low) and the value of the change in gold and other foreign reserves (reserv).

\subsubsection{User cost of capital}

Jorgenson (1963), the pioneer of neoclassical theory, defines the cost of capital as the cost, which the firm incurs as a consequence of owning an asset. The cost 
of capital transforms the acquisition price of an asset into an appropriate rental price, which depends on the rates of return and depreciation. The rate of return is the opportunity cost of holding capital goods rather than financial assets. Depreciation arises from the decline in the price of capital goods with age (Jorgenson, 1993: 4).

The neoclassical theory of capital accumulation is formulated in two alternative yet equivalent ways. First, the firm may accumulate capital to supply services to it own. The objective of the firm is to maximise its value, subject to its technical limitations. Secondly, the firm may rent assets in order to obtain capital services. In this case, the objective of the firm is to maximise its current profit, defined as gross revenue less the cost of inputs less the rental value of capital. The rental can be calculated from the relationship between the price of new capital goods and the discounted value of future services received from these goods (Jorgenson, 1993: 4). According to Jorgenson (1993), in the absence of direct taxes, this relationship takes the form:

$q_{t}=\int e^{(-r)(s-t) c(s)-\delta(\theta-t)} \mathrm{d} s$

where $\mathrm{r}$ is the discount rate, $q$ the price of capital goods, $c$ the cost of capital services and $\delta$ the rate of replacement (depreciation). The time of acquisition is given by $t$ and $s$ is the period over which capital services are supplied (Jorgenson, 1993: 4). Differentiating this with respect to $t$ gives $c=q(r+\delta)-q$, which is the

rental price of capital services supplied by the firm to itself. Under static expectations about the price of investment goods, the rental price reduces to $c=q(r+\delta)$.

To extend the formula to allow for taxation, Jorgenson (1993) defines a depreciation formula $D(s)$ which is used to calculate the proportion of the original cost of an asset of age $s$, which may be deducted from taxes. Jorgenson also assumes a tax credit $k$, which can be deducted from investment expenditure. If the tax rate is constant over time at rate $u$, the equality between the price of investment goods and the discounted value of capital services is:

$q_{t}=\int e^{(-r)(s-t)}\left[(1-u) c(s) e^{-\delta(\vartheta-t)}-u(1-k) q(t) D(s)\right] \mathrm{d} s+k q_{t}$.

The present value of depreciation on one rand's worth of investment is denoted by $z$. The rental value of capital under static expectations then becomes:

$c=q(r+\delta) \times \frac{(1-k)(1-u z)}{(1-u)}$

The effect of tax policy on investment behaviour enters the investment function through the rental value of capital. This results in a change in the desired level of capital. Such a change leads to net investment (or disinvestment), increasing (or decreasing) capital stock to its new desired level (Jorgenson, 1993: 4). 
Table 2

Trace and Eigenvalue tests for cointegration

\begin{tabular}{lllccc}
\hline Test & Null & Alternative & Statistic & $95 \%$ critical value & $90 \%$ critical value \\
\hline Trace & $r=0$ & $r \geqslant 1$ & $18.5571^{\circ}$ & 17.860 & 15.750 \\
& $r \leqslant 1$ & $r=2$ & 0.14125 & 8.0700 & 6.5000 \\
Eigenvalue & $r=0$ & $r=1$ & $18.4158^{\circ}$ & 14.880 & 12.980 \\
& $r \leqslant 1$ & $r=2$ & 0.14125 & 8.0700 & 6.5000 \\
\hline
\end{tabular}

" Reject null hypothesis on $5 \%$ level of significance.

The user-cost-of-capital (r) in nominal terms can be expressed as:

$r=$ price of capital $\left(\frac{(\text { interest rate })+(\text { rate of depreciation })}{1-\operatorname{tax} \text { ratio }}\right)$.

\subsubsection{International positional index}

Du Toit (1999) developed an index reflecting the international position of South Africa. This index is a weighted average of the exchange rate, South Africa's share in world trade, direct foreign investment relative to gross domestic investment, indirect foreign investment relative to gross domestic investment and South Africa's international competitiveness (measured by domestic export prices relative to world export prices).

\subsection{Estimation results}

Johansen's cointegration technique was applied to test whether the variables are cointegrated and to estimate the cointegrating vectors. Both the trace and Eigenvalue tests (see Table 2) confirmed that one cointegrating vector exists. The likelihood ratio does not reject the restrictions of normalisation on the user cost of capital and by restricting the coefficient $(\alpha)$ of the output/capital ratio $(Y / K)$ to a value of

0.65, it becomes the same as the elasticity of capital in a Cobb-Douglas production function. This implies that the long-run level of capital in South Africa is determined in a neoclassical way, in other words capital is employed until the user cost of capital equals the marginal productivity of capital. Investment, which is merely a

Table 3

Cointegration equation: UCC

\begin{tabular}{lcll}
\hline Dependent variable: UCC & & & \\
\hline Variable & Coefficient & & \\
\hline$Y / K$ & 0.65 & LR $\chi^{2}(1)$ & 0.48247 \\
LL: exactly identifying restrictions & 138.7717 & $P$-value(LR) & 0.487 \\
LL: over-identifying restrictions & 138.5305 & & \\
\hline
\end{tabular}


Table 4

Error correction model

\begin{tabular}{lrlrr}
\hline Dependent variable: $\Delta \log (\text { Capital })_{t}$ & & & \\
\hline Variable & Coefficient & S.E. & $t$-Statistic & $P$-value \\
\hline RES $_{t-1}$ & -0.341828 & 0.036665 & -9.323087 & 0.0000 \\
$\Delta \log \left(\mathrm{FIN}_{t-1}\right)$ & 0.021838 & 0.011698 & 1.866805 & 0.0783 \\
$\Delta \log \left(\right.$ INTPOS $\left._{t-2}\right)$ & -0.025769 & 0.010891 & -2.366066 & 0.0294 \\
$\Delta \log \left(\right.$ INTPOS $\left._{t-5}\right)$ & -0.044143 & 0.008958 & -4.927801 & 0.0001 \\
SANCDUM & -0.021201 & 0.002178 & -9.732913 & 0.0000 \\
$\Delta \log \left(\mathrm{UCC}_{t-1}\right)$ & 0.029374 & 0.005797 & 5.066852 & 0.0001 \\
$C$ & 0.023087 & 0.002196 & 10.51445 & 0.0000 \\
Adjusted $R^{2}$ & 0.868766 & $F$-statistic & 27.48001 & \\
S.E. of regression & 0.006265 & Prob $(F$-statistic $)$ & 0.000000 & \\
\hline
\end{tabular}

function of the change in capital, is therefore also driven in the long-run by the user cost of capital and the marginal productivity of capital (Table 3).

After the long-run cointegration relationship was determined, an error correction mechanism (ECM) was estimated in order to capture the short-run or dynamic adjustment process to long-run equilibrium. The estimation results of the ECM are reported in Table 4. Financial constraints, the user cost of capital, the international position and a dummy variable to capture the era of international sanctions against South Africa during the 1980s, were included in the ECM to fully explain the short-run dynamics of capital stock behaviour.

The capital function was subjected to rigorous diagnostic testing. The diagnostic test results reported in Table 5 indicate that the function passes all the statistical diagnostic tests. Dynamic simulation of the final model yields the overall fit depicted in Fig. 2. The capital stock was estimated in order to derive gross domestic fixed investment. Fig. 3 shows actual and estimated gross domestic fixed investment.

\section{Conclusion}

This paper aimed to secure a theoretical approach for modelling aggregate domestic fixed investment in South Africa. The neoclassical (Jorgenson) approach

Table 5

Diagnostic tests

\begin{tabular}{lllcl}
\hline Purpose of test & Test & d.f. & Test & Probability \\
\hline Normality & Jarque-Bera & $\mathrm{JB}(2)$ & 0.32 & 0.85 \\
Homoscedasticity & ARCH LM & $n R^{2}(1)$ & 1.65 & 0.44 \\
Homoscedasticity & White & $n R^{2}(18)$ & 5.75 & 0.11 \\
Serial correlation & Breusch-Godfrey & $n R^{2}(2)$ & 1.65 & 0.44 \\
Serial correlation & Durbin-Watson & DW & 1.52 & \\
Misspecification & Ramsey Reset & LR(2) & 0.02 & 0.90 \\
Parameter stability & Recursive estimates & Indicative of stability & \\
\hline
\end{tabular}


openUP

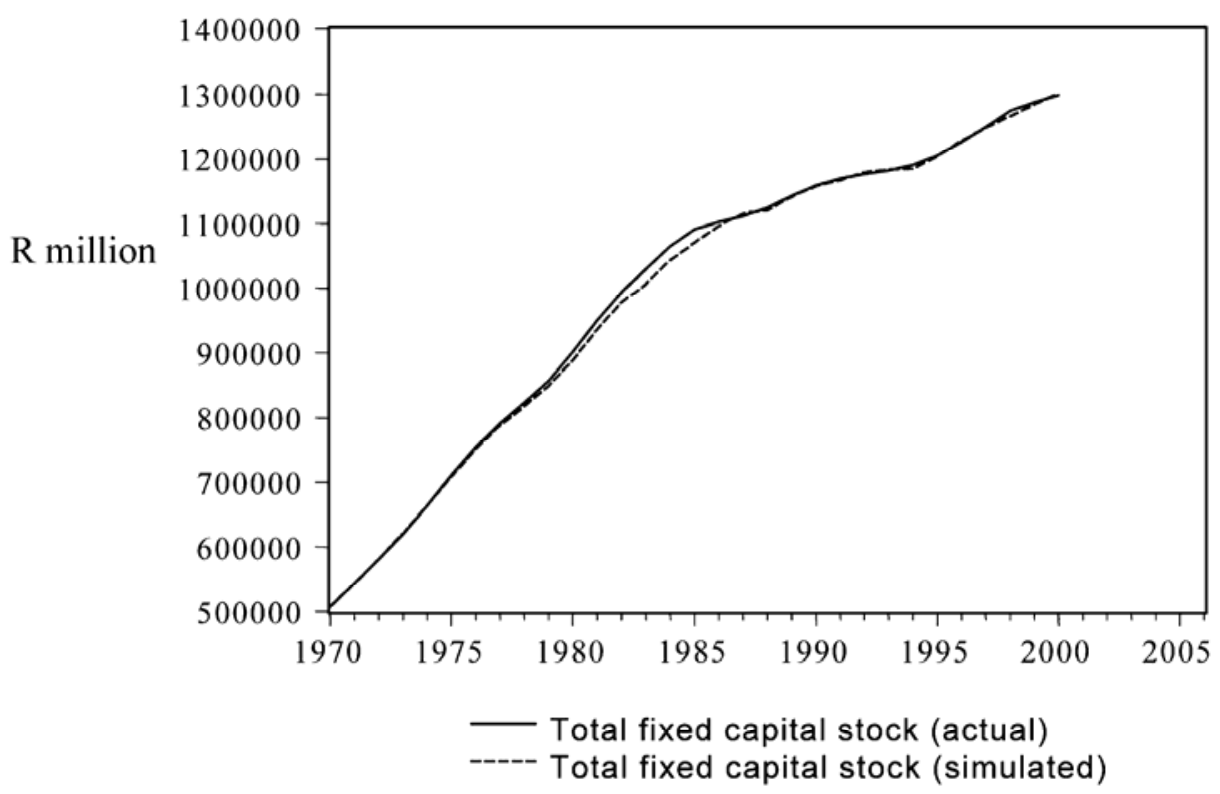

Fig. 2. Actual and fitted values of capital $(K)$.

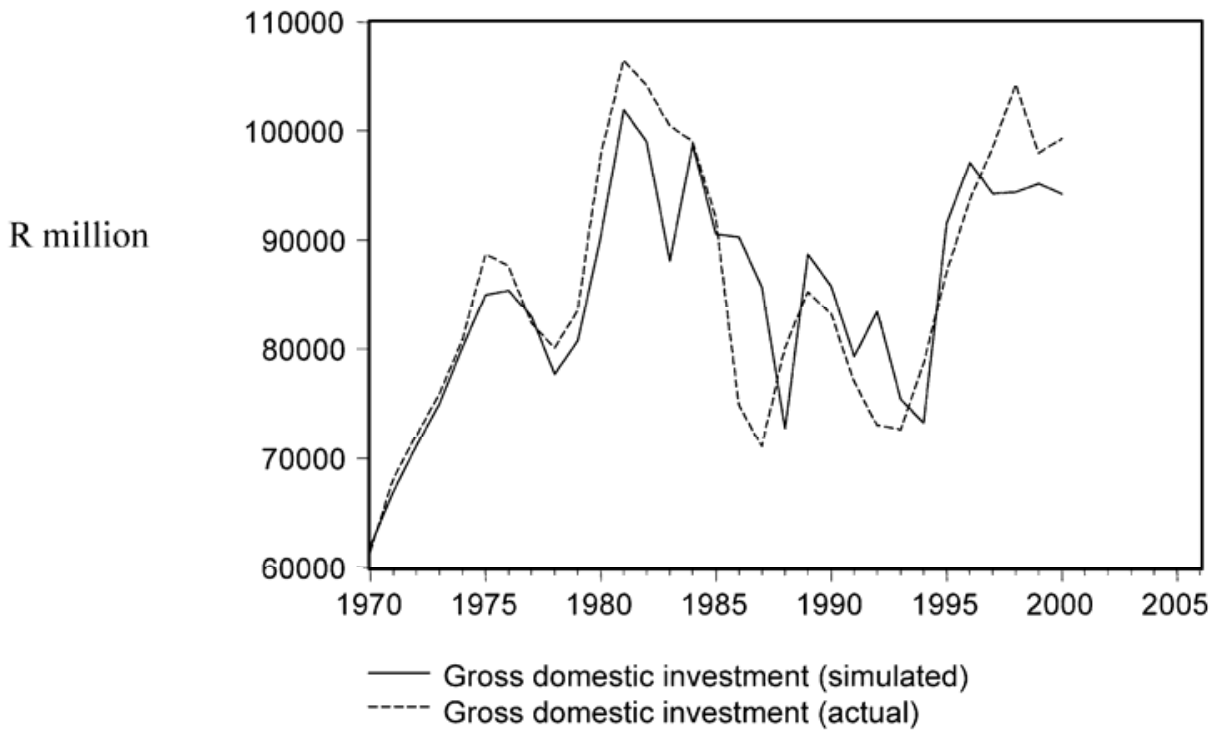

Fig. 3. Gross domestic fixed investment. 
was selected as the most suitable for estimating fixed investment, incorporating all costminimising and profit-maximising decision-making processes by firms. The South African economy's vulnerability to international financial market instability has serious implications for domestic fixed investment. It is therefore necessary to incorporate the significant role of financial constraints (internal and external) on investment. An attempt was made to extend the neoclassical specification by incorporating the financial constraints as specified by cash-flow models, but only on an aggregate level.

According to the results of the empirical estimation, the long-run level of investment in South Africa is indeed determined in a neoclassical way, in other words capital is employed until the user cost of capital equals the marginal productivity of capital. Investment, which is a function of the change in capital, is therefore also driven in the long-run by the user cost of capital and the marginal productivity of capital. In the shortrun, financial constraints, the user cost of capital, the international position as well as a dummy variable which captures the era of international sanctions against South Africa during the 1980s, all significantly influence the dynamics of capital stock and investment behaviour.

These results have critical implications for policy makers in their objective of increasing the productive capacity and future growth of the South African economy, since they have to address the user cost of capital, South Africa's international position and domestic and foreign financial constraints in order to stimulate investment. The user cost of capital, which incorporates the opportunity cost of investing, fluctuations in the price of capital that may lead to capital gains or losses, the depreciation of capital and taxes, stress the importance of addressing all the factors that impose a cost on investors. The importance of financial constraints emphasizes the need to attract foreign capital as well as to stimulate domestic savings in order to stimulate investment. Finally, the significance of South Africa's international position points to the responsibility of policy authorities in maintaining sound economic fundamentals and policies. In addition authorities have to manage market psychology, which includes practicing generally responsible politics and good public governance, influencing perceptions of political and other types of risk and reducing the total cost of doing business in South Africa.

\section{Acknowledgments}

The financial assistance of the National Research Foundation (Grant: 2053334) towards this research is hereby acknowledged. Opinions expressed and conclusions arrived at, are not necessarily attributed to the Foundation.

\section{References}

Berndt, E.R., 1991. The Practice of Econometrics: Classic and Contemporary. Addison-Wesley Publishing Company, New York. Du Toit, C.B., 1999. A Supply-Side Model of the South African Economy: Critical Policy Implications.

Unpublished Thesis. Pretoria: University of Pretoria. 
Grunfeld, Y., 1960. The determinants of corporate investment. In: Harberger, C. (Ed.), The Demand for Durable Goods. University of Chicago Press, Chicago. Jorgenson, D.W., 1963. Capital theory and investment behavior. American Economic Review 53 (2),

247-249. Nickell, S., 1978. Investment Decisions of Firms. Cambridge University Press, Cambridge. South African Reserve Bank. Quarterly Bulletin, various issues. Tobin, J., 1969. A general equilibrium approach to monetary theory. Journal of Money, Credit and

Banking 1 (1), 15-29. 